\title{
Recovery Spring, Faltering Fall: March to November 1933
}

\author{
Jason E. Taylor \\ Central Michigan University \\ 321 Sloan Hall \\ Mount Pleasant, MI 48859 \\ 989.774.2578 \\ Taylo2je@cmich.edu \\ (corresponding author) \\ Todd C. Neumann \\ University of Arizona \\ 1130 E. Helen Street \\ McClelland Hall 401 \\ Tucson, AZ 85721 \\ 520.621 .3790 \\ tcn@u.arizona.edu
}

Keywords: Recovery, Depression, Inflation, Devaluation, Expectations

\begin{abstract}
Recovery from the Great Depression began in March 1933, simultaneous to Franklin Roosevelt's inauguration. However, the pace of that recovery between that date and the Second World War was extremely uneven with some dramatic starts and stops. Between March and July 1933, manufacturing production rose 78 percent, production of durable goods was up 199 percent, total industrial production rose 57 percent, and the Dow Jones Industrial Average rose 71 percent. Then the economy contracted sharply again beginning in August 1933 - the July 1933 level of industrial production was not reached again until August 1935. This paper addresses two questions. What factors were responsible for bringing about the sharp recovery in the spring of 1933 and what factors brought this short-lived economic surge to an end?
\end{abstract}




\section{Recovery Spring, Faltering Fall: March to November 1933}

Recovery from the Great Depression began in March 1933, simultaneous to Franklin Roosevelt's inauguration. However, the pace of that recovery between that date and the Second World War was extremely uneven with some dramatic starts and stops. Between March and July 1933, manufacturing production rose 78 percent, production of durable goods was up 199 percent, total industrial production rose 57 percent, and the Dow Jones Industrial Average rose 71 percent. Then the economy contracted sharply again beginning in August 1933 - the July 1933 level of industrial production was not reached again until August 1935. This paper addresses two questions. What factors were responsible for bringing about the sharp recovery in the spring of 1933 and what factors brought this short-lived economic surge to an end?

\section{Introduction}

The financial crisis of 2008 has placed renewed interest upon what may be its closest historical precedent, the downturn of 1929 to 1933 . Initially scholars focused heavily on parallels in the causes of the two slumps, but more recent emphasis has been placed on aspects of recovery. While there is general agreement that recovery from the Great Recession since 2009 has been slow and unsteady, the swiftness of the recovery from the Great Depression is a source of debate. Those impressed with the recovery note that 1933 to 1937 saw the fastest four year growth in US history. Others express disappointment in the recovery by noting that the unemployment rate remained between 14 and 20 percent until the outbreak of war in Europe.

But there can be no debate that the start of the recovery, which was almost simultaneous to Franklin Roosevelt's taking office in March 1933, was spectacular. Between its March nadir and July manufacturing production rose 78 percent, production of durable goods was up 199 percent, industrial production rose 57 percent, and the Dow Jones Industrial Average rose 71 
percent. Nearly every aspect of the US economy kicked into a gear that has never been seen before or since. If one calculates the four-month growth rates in Industrial Production and Manufacturing Production for every month between November 1884 and May 2014, the March to July 1933 period growth rates are by far the largest. ${ }^{1}$ Excluding periods containing March to July 1933, the next largest four-month period of growth in the United States since 1884 was September 1934 to January 1935, with growth rates of 21.3 and 23.2 in Industrial Production and Manufacturing respectively-around one-third of the growth rates that occurred during the spring of 1933.

While such a torrid pace of growth could not have continued indefinitely, it is interesting to note that had industrial production risen at the 12 percent per month clip it averaged in April, May, June, and July for 3 more months, it would have exceeded its 1929 peak and reached a level it would not ultimately reach until 1936 . Had it grown at this rate for one additional month (i.e. 4 total), industrial production would have exceeded its 1929 levels plus a 3 percent growth trend, a level it would not reach until the Second World War. This is illustrated in Figure 1, where a dashed line extrapolates growth in industrial production at the March to July pace through November 1933. We do not at all mean to imply that the dashed line is a counterfactual — one would strongly expect growth would naturally slow as the economy approached its productive capacity. The line is only meant to show how remarkable these four months of growth were by considering what would have happened had they been duplicated.

\footnotetext{
${ }^{1}$ For 1884 to 1919 , we employed the Miron-Romer seasonally adjusted measure of industrial production and for the post 1919 era we used Federal Reserve Board Industrial Production and Capacity Utilization (G.17), Major Industry Groups, Series B50001.S (Seasonally Adjusted). Romer, Christina. "Remeasuring Business Cycles." Journal of Economic History 54 (September 1994): 573-609.
} 


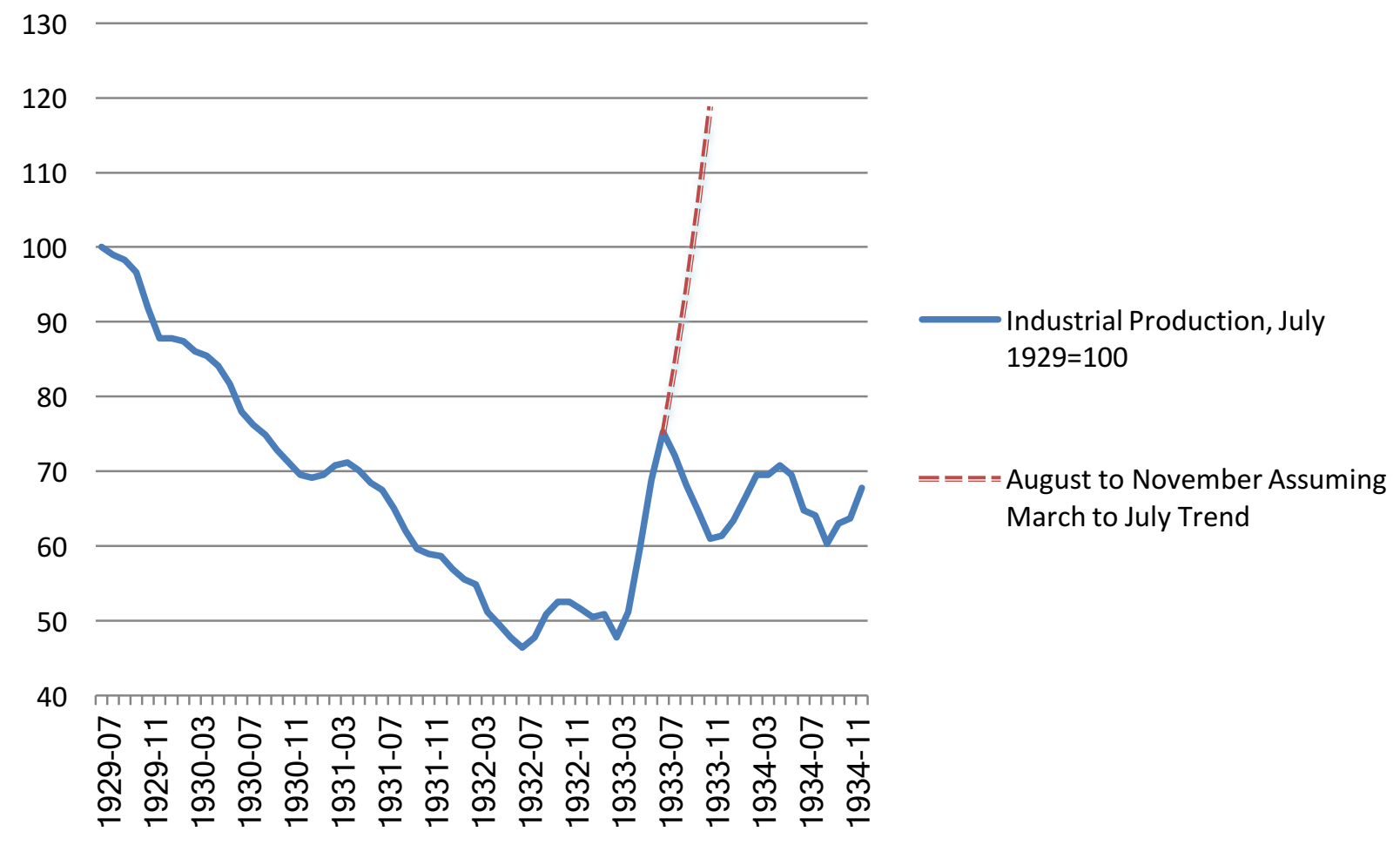

\section{Figure 1 \\ Industrial Production, 1929 - 1934}

Dashed Line shows August through November 1933

Had Growth Continued at 12 Percent per Month Trend of March to July

Source: Federal Reserve Industrial Production and Capacity Utilization (G.17), Major Industry Groups, Series B50001.S (Seasonally Adjusted).

Figure 1 also illustrates that a significant plunge in industrial production began in August 1933. From August to November 1933 manufacturing production fell 31 percent, production of durable goods fell 48 percent, and overall industrial production fell 19 percent making this four month downturn more severe than the 18 month "Great Recession" of 2007-2009 and quite comparable to the depression of 1920-1921. Much of the progress that Recovery Spring brought was offset by the sharp contraction of the late summer and fall of 1933 . While a slowdown in growth was inevitable, such a dramatic turnaround from speedy growth to rapid decline begs an 
explanation. The economy did not again reach its July 1933 level of industrial production until August 1935, at which point it once again began to surge, growing 37 percent over the next 20 months.

This paper has three major goals. First, it documents the extent of the recovery that took place in the spring of 1933. Second, it explores potential factors that drove the recovery. Inflationary expectations have been highlighted in the past literature, but there are several additional factors that could have played supporting roles including financial reforms, currency devaluation, increases to consumer and business confidence, and anticipation of cartelization. Third, it analyzes the causes of the downturn that began in August 1933.

\section{An Unparalleled Economic Season: Recovery Spring 1933}

Hindsight clearly shows that when Roosevelt took office on March 4, 1933, the US economy was at the bottom of a three and a half year slump - the longest and steepest downturn in the nation's history. One may argue that an unprecedentedly sharp recovery could have been expected given the extraordinary depth of the downturn. For some historical perspective, Table 1

compares the five-month recoveries in industrial production and in manufacturing from the four largest downturns of the last 100 years-1920-1921, 1929-1933, 1981-1982, and 2007-2009. The table shows how far each measure was below its prior peak and how much each had risen five months after the trough. While it is certainly true that the downturn of the 1930 s was much more severe-only 1920-1921 even comes close in terms of how far the trough was below peak-it is also clear that the recovery that occurred in the spring of 1933 was unprecedented both in absolute as well as relative terms. 
Table 1

5 Month Recovery of Industrial Production and Manufacturing During Four Major Downturns

\begin{tabular}{cccccc}
\hline \hline \multirow{2}{*}{ Recession } & \multicolumn{2}{c}{ Industrial Production } & & \multicolumn{2}{c}{ Manufacturing } \\
\cline { 2 - 3 } \cline { 5 - 6 } & $\begin{array}{c}\text { \% Decline From } \\
\text { Previous Peak }\end{array}$ & $\begin{array}{c}\text { \% Rise 5 Months } \\
\text { After Trough }\end{array}$ & & $\begin{array}{c}\text { \% Decline From } \\
\text { Previous Peak }\end{array}$ & $\begin{array}{c}\text { \% Rise 5 Months } \\
\text { After Trough }\end{array}$ \\
\hline $1920-1921$ & 32.54 & 1.42 & & 34.82 & 2.74 \\
$1929-1933$ & 52.20 & 57.45 & & 55.38 & 66.67 \\
$1980-1981$ & 9.22 & 3.37 & & 21.22 & 4.60 \\
$2007-2009$ & 17.04 & 2.98 & 20.39 & 3.22 \\
\hline
\end{tabular}

Source: Federal Reserve Industrial Production and Capacity Utilization (G.17), Major Industry Groups, Series B50001.S (Total Index) and B00004.S (Manufacturing SIC). Both series are seasonally adjusted.

It is possible that some of the wide month to month volatility seen in industrial production is measurement error. To gain perspectives broader than simply production of manufacturing output, Table 2 shows the percentage movement in the Dow Jones Industrial Index (DJIA), employment in manufacturing (measured in number of workers on payrolls), average hourly workweek in manufacturing, and hours of labor input (number of workers on payrolls * average hours per week) between the peak of August 1929 and the trough of March 1933, the "Recovery Spring" time period of March through July 1933, and the July 1933 peak though November 1933. Additionally, to see whether different types of production markets were affected differently, we include percentage movements in farm marketings, producer goods, and consumer goods, as well as a broad measure of business activity. The recovery that began with President Roosevelt's inauguration occurred across the board, but was particularly strong in producer goods that surged nearly 115 percent in five months. It is noteworthy that even seasonally adjusted farm marketings were up nearly 5 percent between March and July 1933, although these gains were clearly dwarfed by those in the manufacturing sector. 
Interestingly, this was not a jobless recovery simply driven by gains in worker productivity (output per labor hour). In raw numbers, the average number of hours per week rose from 32.1 in March 1933 to 42.9 in July, reducing the nation's underemployment problem. Likewise number of workers on payroll in manufacturing rose from 5,029,000 in March to $6,155,000$ in July. Putting these two forces together, total labor hours in the manufacturing sector increased by over 103 million hours, a 63.57 percent increase, in just five months.

\section{Table 2}

\section{Percentage Growth in Various Measures Over Three Time Periods}

$\begin{array}{llllllll}\text { Dow } & \text { Employ- } & \text { Average } & \text { Labor } & \text { Farm } & \text { Producer } & \text { Con- } & \text { Index } \\ \text { Jones } & \text { ment } & \text { Hours } & \text { Input, } & \text { Market- } & \text { Goods } & \text { sumer } & \text { Of } \\ \text { Ind } & \text { (\# of } & \text { Per } & \text { Mfg } & \text { ings } & & \text { Goods } & \text { Business } \\ \text { Index } & \text { workers) } & \text { Week, } & & & & & \text { Activity } \\ & \text { Mfg } & \text { Mfg } & & & & & \end{array}$

Aug $29-\quad-83.92 \% \quad-43.02 \% \quad-33.33 \% \quad-62.13 \% \quad-25.00 \% \quad-64.23 \% \quad-38.08 \% \quad-46.1 \%$

March 33

March 33- 70.65\%

$22.39 \%$

$33.64 \%$

$63.57 \%$

$4.76 \%$

$114.95 \%$

$36.51 \%$

$50.9 \%$

July 33

July 33-

$-3.15 \% \quad 6.50 \%$

$-21.21 \%$

$-16.09 \% \quad-3.41 \%$

$-38.55 \%$

$-16.57 \% \quad-19.9 \%$

Notes: Labor Input, Mfg is calculated by multiplying Employment Manufacturing by Hours Per Week, Mfg. Farm Marketings, Producer Goods, and Consumer Goods, and the Index of Business Activity are seasonally adjusted, while the other four measures are not.

Sources: Dow Jones Industrial Average, NBER Series m11009b; Employment in Production, NBER Series m08010; Average Hours Per Week, Mfg, NBER Series m08029; Index of Agricultural Marketings, NBER Series 12009; Producer Goods NBER Series M01055; Consumer Goods NBER Series M01056. Seasonally Adjusted Index of Business Activity is from Survey of Current Business.

To further address the extent to which the output burst of Recovery Spring was facilitated by either productivity enhancements or businesses expanding employment, we analyze a few important industries. Industry employment data are reported as indices rather than actual number 
employed. Still we can roughly approximate productivity growth in an industry by subtracting the labor input growth rate from the growth rate in the industry's output, where the labor input growth rate is calculated as the monthly growth rate of the product of the employment index and average hourly workweek. Table 3 reports output, employment, and average workweek for four time periods_-July 1932, March 1933, July 1933, , and November 1933 (the November data will be discussed in section 5). The July 1932 data is included for comparison to July 1933 because some of these industries have strong seasonal movements. The final three columns include percentage growth in output between March and July 1933, as well as between July and November 1933, percentage growth in labor input between the same period, as well as our approximation of productivity growth between March and July 1933.

Clearly Automobiles and Steel, industries that are strongly tied together, experienced extremely fast growth during Recovery Spring. Comparisons to the July 1932 data show that this performance was not driven by seasonal factors alone. In the case of Automobiles, labor input (total hours worked) usage grew faster than output between March and July 1933. About two thirds of the growth in labor input can be attributed to longer average workweeks while the remaining one third can be attributed to increases in number of workers. Steel production jumped a remarkable 253 percent between March and July1933, and in this case productivity increases drove a large portion of this run-up. Still, total labor hours more than doubled during these five months in steel factories and once again about two thirds of this run up can be attributed to longer workweeks. ${ }^{2}$

${ }^{2}$ Interestingly, the steel industry was viewed early in the recovery as a "weather-vane" for the economy more broadly. An April 20 analysis on the financial pages of the New York Times noted that steel had seen "more substantial improvement than any other major industry" in the past few weeks. Steel executives noted that "the next two weeks will determine whether the pick 
Table 3

Performance of Various Industries

\begin{tabular}{|c|c|c|c|c|c|c|}
\hline Industry & Output & $\begin{array}{l}\text { Employment } \\
\text { Index }\end{array}$ & $\begin{array}{l}\text { Average } \\
\text { Work- } \\
\text { Week } \\
\text { (Hours) }\end{array}$ & $\begin{array}{l}\% \text { Growth } \\
\text { Output } \\
\text { March-July } \\
\text { July-Nov }\end{array}$ & $\begin{array}{l}\% \quad \text { Growth } \\
\text { Labor Input } \\
\text { March-July } \\
\text { July-Nov }\end{array}$ & $\begin{array}{l}\text { Estimated } \\
\text { Productivity } \\
\text { \% Growth } \\
\text { March-July }\end{array}$ \\
\hline Automobiles & \# of cars & & & & & \\
\hline July 1932 & 95,000 & 56.0 & 20.5 & & & \\
\hline March 1933 & 97,000 & 50.1 & 26.7 & & & \\
\hline July 1933 & 191,000 & 66.8 & 40.7 & 96.91 & 103.25 & -6.34 \\
\hline November 1933 & 42,000 & 57.5 & 30.3 & -78.01 & -35.92 & \\
\hline Chemical Mfg & Index & & & & & \\
\hline July 1932 & 59 & 77.1 & 37.5 & & & \\
\hline March 1933 & 68 & 88.8 & 38.5 & & & \\
\hline July 1933 & 84 & 103.2 & 41.5 & 23.53 & 25.27 & -1.74 \\
\hline November 1933 & 81 & 113.7 & 37.5 & -3.57 & -0.45 & \\
\hline Machinery & Index & & & & & \\
\hline July 1932 & 36 & 43.4 & 28.3 & & & \\
\hline March 1933 & 34 & 42.6 & 28.2 & & & \\
\hline July 1933 & 57 & 49.5 & 40.9 & 67.65 & 68.53 & -0.88 \\
\hline November 1933 & 63 & 62.9 & 35.7 & 10.53 & 10.92 & \\
\hline Paper and Pulp & Short Tons & & & & & \\
\hline July 1932 & 561,400 & 78.9 & 37.7 & & & \\
\hline March 1933 & 671,500 & 78.3 & 39.1 & & & \\
\hline July 1933 & 923,800 & 88.5 & 46.6 & 37.57 & 34.71 & 2.87 \\
\hline November 1933 & 785,400 & 100.8 & 37.0 & -14.98 & -9.57 & \\
\hline Shoes & Pairs & & & & & \\
\hline July 1932 & $7.52 \mathrm{mil}$ & 80.9 & 40.9 & & & \\
\hline March 1933 & $7.26 \mathrm{mil}$ & 88.2 & 39.5 & & & \\
\hline July 1933 & $15.07 \mathrm{mil}$ & 96.5 & 49.7 & 107.58 & 37.66 & 69.91 \\
\hline November 1933 & $12.76 \mathrm{mil}$ & 83.2 & 34.6 & -15.33 & -39.98 & \\
\hline Steel & Tons per day & & & & & \\
\hline July 1932 & 29.5 & 54.2 & 24.6 & & & \\
\hline March 1933 & 33 & 57.2 & 26.8 & & & \\
\hline July 1933 & 116.4 & 75.3 & 42.4 & 252.73 & 108.27 & 144.46 \\
\hline November 1933 & 57.7 & 81.5 & 31.2 & -50.43 & -20.36 & \\
\hline
\end{tabular}

Notes: Industry-level "codes of fair competition" were passed on the following dates: Autos, August 26, 1933; Chemical Manufacturing, February 10, 1934; Machinery, March 17, 1934; Paper and Pulp, November 17, 1933; Shoes, October 3, 1933; Steel, August 19, 1933.

up is a flash in the pan or the forerunner of a broad expansion." ("Topics in Wall Street," New York Times, April 20, 1933, p. 27.) 
Sources: Automobiles from NBER Series m8144 (employment), m8201a (hours), m1107 (output); Chemical Manufacturing from NBER Series m8216a (employment), m8214a (hours), m1279a (output); Machinery from NBER Series m8224 (employment), m8222 (hours), m1277a (output); Paper and Pulp from NBER Series m8104 (employment), m8234a (hours), m1105 (output); Shoes from NBER Series m8103 (employment), m8199a (hours), m1099 (output); Steel from NBER Series m8015 (employment), m8208a (hours), m1135 (output).

Shoe production also more than doubled during Recovery Spring from 7.26 million pairs in March to over 15 million pairs in July. In this industry the employment gains were far less dramatic than those seen in autos and steel as the industry had only a little over 9 percent more workers on payrolls in July than it did in March, although the average workweek did rise over 25 percent. The Machinery, Chemicals, and Paper industries all saw very little change in worker productivity as growth in output and growth in labor inputs closely mirrored each other, each growing between 23 and 68 percent. With respect to magnitude, we cannot rule out some measurement error in the wide swings in output. Still, it is noteworthy that output rose between March and July 1933 in 39 of the 42 industries for which we have monthly output data- the nonweighted average increase was 64.6 percent across these months. Coupled with additional data from other sectors, it is hard to deny that the spring boom was anything less than extraordinary.

\section{What Drove Recovery Spring?}

Romer (1992) argues that the rapid growth between 1933 and 1937 can be attributed to conventional aggregate demand stimulus in the form of monetary expansion. However, her work focuses broadly on the four-year recovery—she uses annual data—rather than the turning point. Temin and Wigmore (1990) produced the seminal paper with respect to analyzing the beginnings of the sharp recovery of spring 1933 . The authors argue that the recovery that began with 
Roosevelt's inauguration was driven by a regime change a la Sargent (1983). President Roosevelt broke dramatically from Herbert Hoover's deflationary polices by removing the US from the gold standard and devaluing the dollar, promoting fiscal expansion, and championing the virtues of inflation. According to Temin and Wigmore, "the devaluation of April-July 1933 was the proximate cause of the recovery." The devaluation, the authors note, had direct effects on prices and production throughout the economy - particularly in agriculture where commodities prices such as those on grain and cotton rose dramatically creating a large income effect for farmers who in turn stepped up their purchase of durable goods like cars - and also had indirect effects through its signal of a new inflationary policy regime. Eggertsson (2008) extends Temin and Wigmore by employing a dynamic stochastic general equilibrium model that reaffirms the notion that the regime change that Roosevelt brought generated an endogenous shift in inflationary expectations that stimulated aggregate demand and brought about the end of the Great Depression. Eggertsson's calibrations suggest that around threequarters of the recovery in inflation and output between 1933 and 1937 can be explained by the regime shift.

Hausman (2013) offers empirical support to the Temin and Wigmore's hypothesis by showing that auto sales rose much faster between March and July 1933 in rural agricultural states than in urban ones. But Hausman also notes that higher agricultural prices, while creating a positive income effect for farmers, would have had a negative effect on urban manufacturing workers. One way that higher crop prices could have had a simulative effect on the macroeconomy—rather than on just the agricultural sector-Hausman (p. 127) argues, is if they also "raised urban consumption by creating expectations of future prices"- a hypothesis which 
the author supports through narrative evidence including several newspaper advertisements in May and June 1933 suggesting that consumers buy now before prices rise further.

Jalil and Rua (2014) note that while Temin and Wigmore (1990) and Eggertsson (2008) create a "strong theoretical basis and compelling historical argument" for the notion that inflation expectations were behind the turnaround of spring 1933, neither provides much direct evidence that inflation expectations actually changed. In fact, the estimates of inflationary expectation of Ceccehetti (1992) and Hamilton (1992) do not generally show strong jumps in inflationary expectations until the third quarter of 1933, well after the recovery began. Jalil and Rua note, however, that the time-series methodology of these two studies assumes that market participants form expectations based upon previous trends, and that this assumption may not apply during a major regime shift. Jalil and Rua examine narrative evidence from contemporary media and business analysts and perform an event analysis using data on the number of times the word "inflation" appears in newspaper articles. They show that financial markets reacted positively when inflationary events occurred. Their findings support the notion that inflation expectations surged in the second quarter of 1933, and thus provide direct evidence for the regime change that Temin and Wigmore and Eggertsson claim. Jalil and Rua also attempt to tease out the macroeconomic effects of the policy regime shift by including a dummy variable for April to July 1933 in Bernanke's (1983) regressions in which output is dependent upon money and financial crisis indicators. This exercise suggests that between 48 and 88 percent of the surge in industrial production between March and July 1933 was caused by the regime shift.

\section{A Narrative Study of Inflation Expectations}

We examined the New York Times and the Wall Street Journal to look for evidence as to 
whether contemporaries 1) reported a clear shift in inflation expectations and 2) whether they attributed the recovery of the spring 1933 to inflation expectations. Ultimately, our analysis agrees with Jalil and Rau (2014) - a shift in inflation expectations clearly did occur in the spring of 1933. However, we question whether the timing of this change could have been responsible for the turning of the corner, which appears to have happened in mid to late March. Rising inflation expectations certainly fed the recovery in May, June, and July, but it is less clear as to whether to what extent they are responsible for the initial rise out of the trough.

Jalil and Rau's narrative evidence points to April 19, when the nation abandoned the Gold Standard - importantly, an action that the authors claim was unanticipated-as the first major turning point in inflation expectations and the Senate passing the Farm Relief Bill at the end on April 28 as the second. We agree that these were two major events that shifted inflation expectations. ${ }^{3}$ We also believe that the narrative evidence suggests that the events of April 28 were not fully anticipated (Jalil and Rau do not specify whether or not this event was anticipated). The New York Times financial pages noted that the surge in markets-the DJIA rose 2 percent on Friday the $28^{\text {th }}$ and then another 6.4 percent on Monday May 1, when markets reopened — clearly suggested that economic actors had not fully anticipated the bill's passage. There were likewise "violent repercussions" in the foreign exchange market where the dollar fell precipitously against all major currencies. ${ }^{4}$

${ }^{3}$ There was a small surge in inflation expectations following the emergency gold embargo of March 9, 1933, but our narrative analysis shows that this abated. For example, when stocks declined significantly on March 21, the New York Times financial section attributed this to views that the 'inflation scare' of prior weeks had been overblown. Speculators had been "deluded by the emergency gold embargo applied here at the beginning of the bank holiday" into thinking that this was the first step toward devaluation. The market's decline reflected a retreat in these inflationary expectations.

4 "Financial Markets: Stocks and Commodities Advance Sharply-Foreign Currencies Rise Against the Dollar," New York Times, April 30, 1933, p. 7N. 
Importantly however, not all reactions to the April 28 "inflation bill" were positive. On May 1, the Times financial pages expressed hope that the "mischievous proposals" would not be as damaging as the "inflation manias of our past history." venture of a government ... into currency manipulation, has always led to awkward problems not foreseen" and a fear that "the ancient traditions and principles of public finance are no longer operative."6 Even exporters were not immune to the pessimism. They felt that quotas and tariffs imposed by trading partners would soften, if not destroy, any advantage to exports that devaluation would bring. For these reasons, the Times editorial board argued "the theoretical advantages of depreciated currency in international commerce seldom materialize in practice."7 The misgivings regarding inflation did not abate in the following weeks. On May 14 it was reported that bankers were advocating more control of the currency markets, fearing that "the unstable condition in the foreign exchange market ... could explode at any time in a violent rally of the American monetary unit."8

While business activity increased in the week following the passage of the bill, analysts at Dun \& Bradstreet concluded that "not all of the advances in commodities can be traced to inflationary moves, as the rise of many staples has been supported by a strong statistical base and continued broadening of general business improvement." A May 2 editorial in the Wall Street Journal agreed with this analysis, stating that in addition to the inflation expectations, "there have also been positive indications, notably the pronounced increase in steel production, of a natural improvement in business conditions not attributable to the prospects for intentional

\footnotetext{
5 "Course of the 'Inflation Movement'-Facts and Fallacies of the Hour," New York Times, May 1,1933, p. 21.

6 "Gold Bonds and Inflation," New York Times, May 2, 1933, p. 16

7 “Cheaper Dollars and Trade," New York Times, May 6, 1933, p. 12

8 "Control of Inflation in Exchange Urged," New York Times, May 14, 1933, p. N7

9 “'Business Revival Broadened in Week," New York Times, May 6, 1933, p. 26
} 
inflation." ${ }^{10}$ On May 10 the Times editorial board explained that "the initiative for better business must have occurred before the talk of currency tinkering began" and that while speculators had "been busy," it was clear that "prices were already rising for other reasons." ${ }^{, 11}$ Recovery, at this point, was seen as an inevitability "to be expected under any circumstances." 12

\section{Timing of Monthly Data}

The monthly data suggest that March saw a decline in industrial production and other economic measures-March was the nadir of the Great Depression. The monthly data suggest that the upswing began in April-for example industrial production rose 7.1 percent in April after falling 6 percent in March while manufacturing output rose 18.5 percent after falling 8.6 percent in March. It is important to note that monthly data series, from broad industrial production to specific industry-level measures of output, wages, and employment were collected by the Bureau of Labor Statistics and other government agencies through surveys of firms, whereby these surveys generally reflect the pay period ending nearest the $15^{\text {th }}$ day of the month - the numbers are extrapolated to reflect the full month. ${ }^{13}$ Thus, the monthly data generally reflect conditions in the first half of the month, rather than the full month.

March 15 fell on Wednesday in 1933 and thus it is likely that the pay period ending nearest to that date would have been March 17 or 18. April 15 fell on Saturday and hence the pay period ending nearest that date would likely have been April 14 or 15. Therefore, the March 1933 data generally reflect economic conditions during the 10 day bank holiday, which ended

\footnotetext{
10 "Review and Outlook: The Prospect for Inflation," Wall Street Journal, May 2, 1933, p. 6

11 "Recovery in the Markets," New York Times, May 10, 1933, p. 16

12 "The Course of Recovery-Various Aspects of the Changing Economic Picture," New York Times, May 15, 1933, p. 21

${ }^{13}$ Today the BLS surveys are to reflect the pay period containing the $12^{\text {th }}$ day of the month.
} 
March 14 and will be discussed in the next section, and the April data reflect conditions prior to the two surprise announcements signaling inflation which occurred on April 19 and April 28. Growth accelerates in May when industrial production jumps by an astounding 16.6 percent, and this jump was very likely aided by rising inflation expectations in connection to the two events pointed out by Jalil and Rau.

To summarize, we agree with the past literature that a jump in inflation expectations occurred in the spring of 1933-specifically it appears that this jump began in late April and accelerated in May. We agree that these had a positive effect on the recovery and were an enormous driver of Recovery Spring. But the narrative evidence suggests that the corner may have been turned before inflationary expectations took off. In the next section we explore what other factors may have driven the recovery aside from changing expectations of future prices.

\section{Aside From Inflation Expectations, What Else Could Have Spurred Recovery Spring?}

Eggertsson (2008) claims that around three-quarters of the recovery of 1933 to 1937 was driven by a regime shift in inflation expectations while Jalil and Rua (2014) estimate that between half and seven-eighths of the recovery of spring 1933 was likewise driven by inflationary regime change. What other factors may have helped account for the economic surge of spring 1933 ?

First, we can rule out the direct monetary factors that Romer (1992) and Friedman and Schwartz (1963) point toward for the 1933 to 1937 recovery. While the money stock rose 46 percent over these four years, it hit bottom in April 1933 and rose only 1.4 percent between April and July. By the end of 1933, the money stock had risen only 3.6 percent above its April low 
point. ${ }^{14}$ We believe we can also rule out direct fiscal factors. Between March and July 1933, the government spent $\$ 2.13$ billion while collecting only $\$ 1.06$ billion in revenues. Interestingly, however, between the same months for 1932, the government spent $\$ 2.26$ billion while collecting only $\$ 811$ million in revenue - net fiscal expansion was substantially larger during March to July 1932 than it was during March to July 1933, and thus it is difficult to attribute Recovery Spring to direct fiscal stimulus, although it could be argued that Roosevelt's creation of several emergency agencies and programs may have increased expectations for future deficits, thus working through the expectations channel emphasized by Eggertsson $(2008,2012) .{ }^{15}$

\section{Banking System Reform}

One viable candidate that could have helped drive recovery in the spring of 1933 is the healing of the banking and financial system. On March 5, 1933 a nationwide bank holiday was instituted and four days later the Emergency Banking Act was signed into law. On March 12, Roosevelt provided what Dighe (2011, p. 51) calls "the ultimate boost to public confidence in the banks" with his fireside chat to 60 million Americans about what the Administration was doing to create a stable and effective banking system. Dighe documents the success of the banking holiday—banks began to open in stages beginning March 14—and contends that the policy had a dramatic positive effect on public confidence. On March 14, the Wall Street Journal declared the banking crisis over, owing in no small part to the steps taken by Roosevelt and Congress. ${ }^{16}$

\footnotetext{
${ }^{14}$ Money Supply data are from NBER Series m14144a, "Money stock, commercial banks plus currency held by public, seasonally adjusted."

${ }^{15}$ Government spending and government revenue data are from NBER Series m15005 and m15004 respectively.

16 “Bank Crisis Passes; U.S. Credit Comes Next," Wall Street Journal, March 14, 1933, p. 1.
} 
When stock markets opened on March 15, after voluntarily suspending trading coincident with the bank holiday, the Dow Jones Industrial Average recorded its largest one-day percentage gain in history of 15.3 percent. Roosevelt advisor Raymond Moley famously said that, "Capitalism was saved in eight days" (Dighe, 2011, p. 41). The following day the New York Times wrote, "investors and traders promptly showed their approval of the reconstruction program of President Roosevelt."17

In fact, a large literature beginning with Schumpeter (1911), with more recent important contributions from Levine (1997) and Rajan and Zingales (1999), amongst others, shows that effective financial intermediaries enhance economic efficiency and promote faster economic growth by helping allocate capital to its best uses. Still, measuring the impact of a healthy and effective financial system is challenging. One avenue would be to examine whether credit became more plentiful following the banking reforms of March 1933. Figure 2 shows that while the extension of credit toward the purchase of new automobiles rose sharply in the spring of 1933 relative to the spring of 1932, the seasonal jump was not dramatically out of line from years prior. Figure 3 also shows that while the value of loans issued by Federal Reserve member banks hit its low point in March 1933, the rise that followed was far from inspiring. Consistent with this, Bernanke (1983, p. 272) notes that lenders "emerged from the 1930-1933 episode chastened and conservative." Friedman and Schwartz (1963, pp. 449-462) note that banks shifted away from making loans of any kind toward holding safe, liquid assets. Both Friedman and Schwartz and Bernanke note that the increase in bank liquidity after the bank holiday of 1933 created the illusion of easy money, even though lending was tight. Of course, a similar phenomenon was argued to be at work after the financial crises of 2008.

17 “Stocks Soar as Trading Resumed,” New York Times, March 16, 1933, p. 1. 
Figure 2

Automobile Installment Credit Extensions, Millions of Dollars

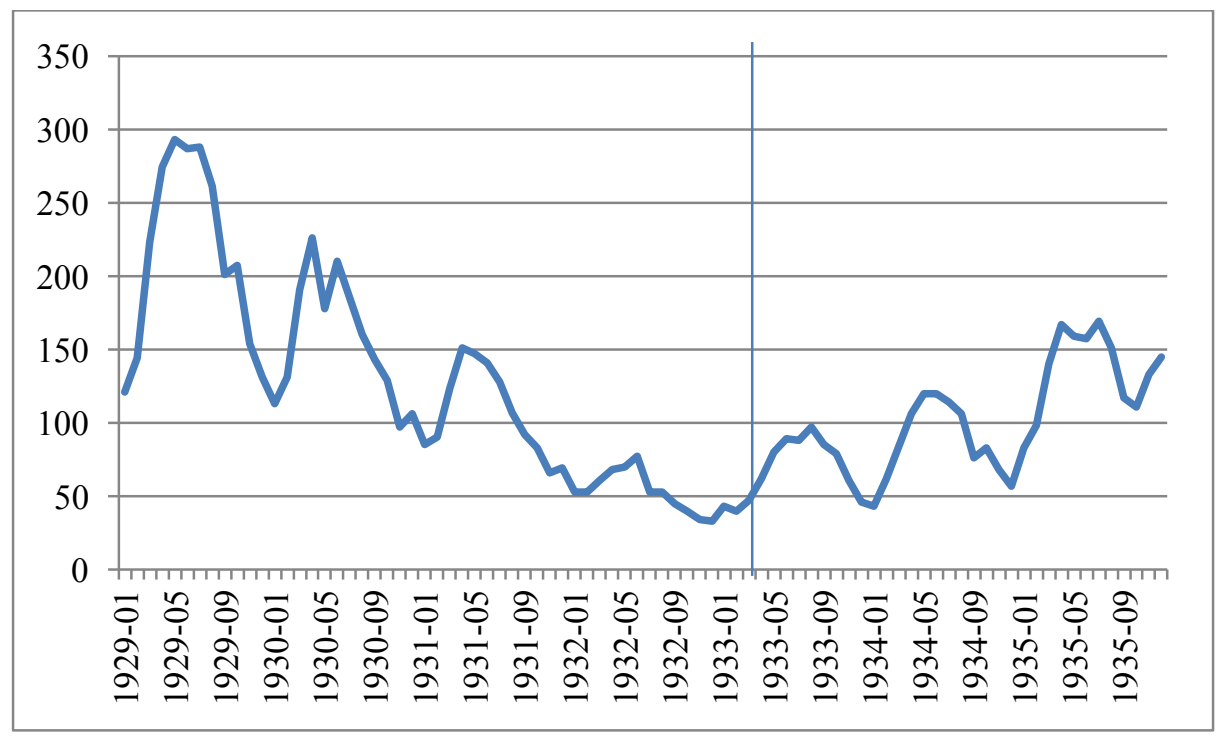

Source: Federal Reserve Board. Federal Reserve Bulletin, June 1955.

Figure 3

Total Loans (Including on Securities), All Member Banks of Federal Reserve System, Billions of Dollars

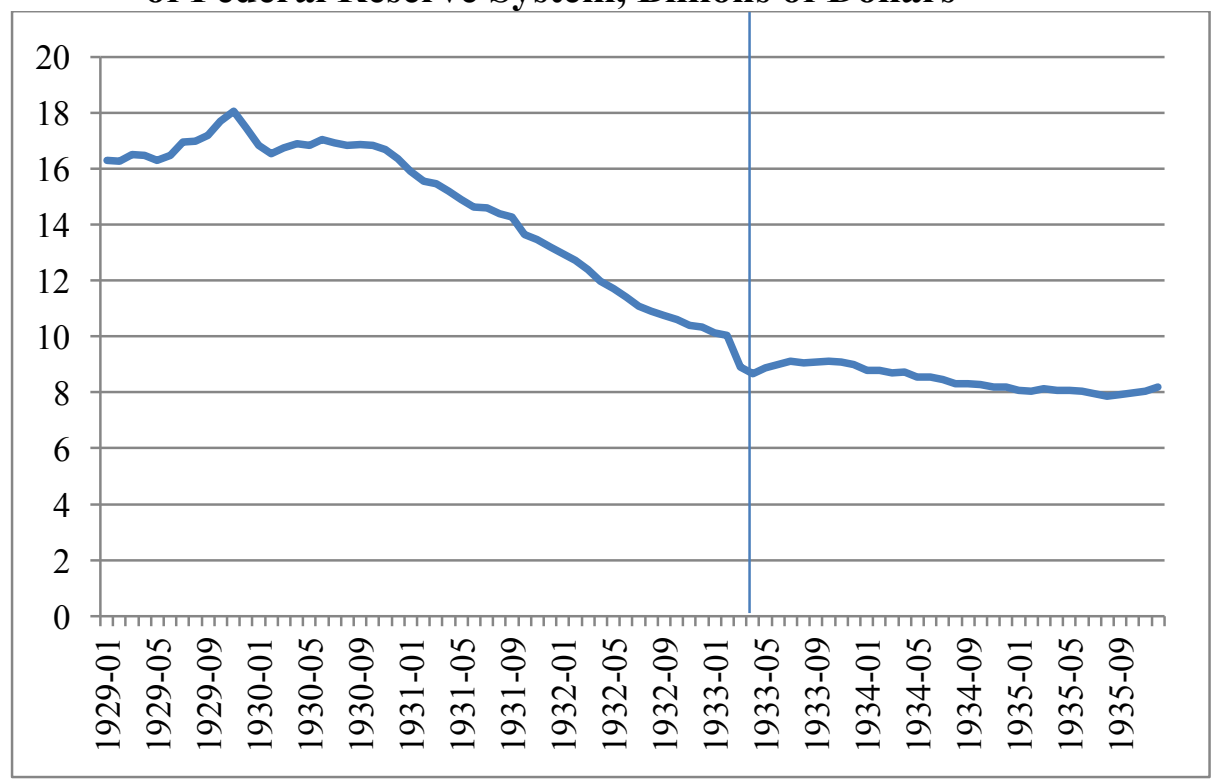

Source: Federal Reserve Board, Annual Reports. Complied in NBER Macrohistory Database, Series 14074 and 14075. 
Devaluation and Trade

Temin and Wigmore claim that, in addition to its indirect effects on inflation expectations, devaluation played a direct role in Recovery Spring by making US exports cheaper overseas and foreign imports more expensive.

\section{Estimation}

To test the extent of direct effects that a healthy financial system may have had on Recovery Spring, we use a two-step model. In the first stage we employ a typical event study technique. Specifically the following regression is run:

$$
\begin{aligned}
\text { OUTPUT }_{t}= & \beta_{0}+\beta_{1} \text { EXCESSRESERVE }_{t}+\beta_{2} \text { TRADE }_{t}+\beta_{3} \text { GOVSPD }_{t}+\beta_{4} G O V R E V_{t}+ \\
& \beta_{2} \text { MONEYSUPPLY }_{t}+\beta_{6} \text { CPI }_{t}+{\text { MONTHFIXEDEFFECT }+\varepsilon_{t}}^{+1)}
\end{aligned}
$$

OUTPUT

$t$.

EXCESSRESERVE

$T R A D E_{t}$

GOVSPD

GOVREV

$M O N E Y_{t}$

$C P I_{t}$

MONTHFIXEDEFFECT = a dummy variable for each calendar month to account for
$=$ growth rate of production (in units, not dollar amounts) in month $=$ growth rate in the percentage of reserves held to required in month $t$.

$=$ growth rate of exports in month $t$.

$=$ growth rate of government spending in month $t$.

$=$ growth rate of government revenues collected in month $t$.

$=$ growth rate of the money supply in month $t$.

$=$ growth rate of the Consumer Price Index in time $t$.

seasonality.

While most of these variables are self-explanatory, EXCESSRESERVE $E_{t}$ requires further explanation. We use this measure as a proxy for the general health of the banking system. In normal times, banks hold almost no excess reserves so that the percentage of reserves held to 
those required is just above 100 percent. When the financial system is not healthy, banks are more likely to hold excess reserves for fear of a panic or crisis. Indeed, in the 1920s, banks held an average of 101.5 percent of reserves to what was required of them. Between 1931 and 1935, in an average month the number was 143.5 - banks held large amounts of excess reserves as a reflection of the relatively unhealthy financial system. Of course banks behaved similarly in the aftermath of the 2008 financial crisis in the US.

Our estimation window is July 1921 through December 1932. Our event window is March of 1933 through July of 1933. As is standard, we then use the coefficients from the estimation window to predict the "cumulative abnormal return" during the event window. As is standard, the cumulative abnormal return is the summed difference over the event window of the actual growth rate in output and what is predicted from the estimation window coefficients. The estimated average cumulative abnormal return between March and July 1933 is 0.38 with a Huber/White robust standard error of 0.065 . This suggests that a shock unaccounted for in the model occurred in the event window, that we call "Recovery Spring."

Because the equation is estimated separately by industry, the coefficients are no doubt different across industry. We can interpret these differing coefficients as a measure of how sensitive a given industry was to changes in the right hand side variables. Of particular interest are the coefficients on EXCESSRESERVE $E_{t}$ and $T R A D E_{t}$ as they proxy for how sensitive each industry's output is to the health of the financial system and to trade. Coefficients on EXCESSRESERVE $E_{t}$ from the first stage are generally positive and range between -3.3 and 8.4 with a median of 0.26 . Coefficients on $T R A D E_{t}$ are generally positive and range between -0.96 and 1.07 with a median of 0.10 . This suggests that the typical industry saw its output rise when the nation's financial system was healthier and when the total volume of exports from the US 
increased, although clearly industries were differently affected by the health of the financial system and trade.

We next use these coefficients in a 62 industry cross-sectional regression as follows:

CUMMULATIVE ABNORMAL RETURN ${ }_{i}=\beta_{0}+\beta_{1}$ BANKHEALTHSENSITIVITY $_{i}+$

$$
\beta_{2} \text {TRADESENSITIVITY }_{i}+\varepsilon_{i}
$$

where

BANKHEALTHSENSITIVITY $_{i}=$ The coefficient by industry on EXCESSRESERVEt from the first stage regression above.

TRADESENSITIVITY $_{i} \quad=$ The coefficient on TRADE from the first stage regression above.

The results are consistent with the devaluation playing a direct role in recovery by disproportionately helping those industries who benefited from greater trade. The coefficient on TRADESENSITIVITY $_{i}$ is 1.11 with a boot strapped standard error of $0.34 .{ }^{18}$ In addition to looking at exports, we also performed the analysis looking at total trade in the first stage regression. The coefficient on TRADESENSITIVITY $i$ becomes smaller when trade is defined this way. The finding that industries where exports were important experienced a more pronounced recovery in the spring of 1933 than otherwise is consistent with Temin and Wigmore's conclusion that devaluation played a major role in recovery. Our results, however, find no evidence that healthier financial system — and the (albeit modest) increases in credit extensions that came with it-contributed significantly to the recovery. The coefficient on bank health

\footnotetext{
${ }^{18}$ Bootstrapped standard errors computed by estimating the first stage separately for each industry and collecting the coefficients of interest. We then use those coefficients in the second stage. To get standard errors we replicate this process over 1000 random draws.
} 
sensitivity is 0.02 with a boot strapped standard error of 0.04 . This indicates that industries where historical growth was more dependent on the health of the financial system did not see a statistically different recovery compared to other industries during the spring of 1933 . We duplicated this analysis looking at total loans rather than percentage of reserves banks held to required and found nearly identical results. Despite the fact we find no statistically significant relationship between bank health sensitivity and recovery we cannot rule out the possibility a healthy financial system playing an important role. It almost certainly helped all industries, not just those sensitive to credit, through the confidence and inflation expectations channels.

\section{Improved Consumer and Business Confidence}

Another factor that could have helped drive Recovery Spring is improved consumer and business confidence. Economic theory suggests that expectations/confidence can affect current spending and this contention has found broad, though not universal, empirical support (Matsusaka and Sbordone, 1995, Carroll, Fuhrer, and Wilcox, 1994). It is important to note that consumer/business confidence is a distinct channel from rising inflation expectations. Business and consumers can shift their expectations toward improved real profits, wages, and employment opportunities even when inflation expectations remain constant or even fall-the United States during the expansion of the 1990s provides an example of such an event. Furthermore, rising inflation expectations can potentially bring increased pessimism, rather than optimism, from economic actors, as was the case in the 1970s when inflation was above its generally desired level. Roosevelt's fireside chats and policy speeches, not just those about the bank holiday and the financial system, clearly delivered a calming influence on the economy. This rise in general 
expectations - inflation expectations aside - could have created a major uptick in economic activity as firms began hiring and consumers began spending again.

In fact narrative evidence from the New York Times and Wall Street Journal suggests that confidence improved almost coincident with Roosevelt taking office. In the weeks after Roosevelt's inauguration, the Times consistently reported that an undertone of optimism was percolating throughout the nation and that this was brought about by the public's views of the new administration. The editorial board declared Roosevelt a "strong tower of hope" for Americans and noted that even his declaration of the bank holiday came with "a ring of confidence. Instead of alarming the country, it seemed to cheer it up."19

By April 14, conditions had improved enough for the Wall Street Journal to conclude that there was "evidence [that] business is on the upgrade." ${ }^{20}$ Citing an unexpected increase in demand, the April 13 New York Times reported that the automobile industry "has been making repeated upward revisions in production schedules [and consequently] demand for steel has increased sharply in the last two weeks, and the increase has been reflected promptly by heavier steel mill operations." ${ }^{21}$ Two days later a Times business article attributed "improved sentiment" for an expansion of business in basic industries, including automobiles and steel. The article also hinted that the Cullen-Harrison Act, also known as the "beer bill," which allowed the production and sale of beverages with 3.2 percent alcohol or less beginning on April 7, 1933, could have played some role. The "chief evidence of improved business since the bank holiday has been

\footnotetext{
19 "Reasons for Hopefulness," New York Times, March 9, 1933, p. 12.

20 "More Cotton Consumed," Wall Street Journal, April 14, 1933, p. 8

21 "Steel Output Up Sharply in Week," New York Times, April 13, 1933, p. 25.
} 
quickening of trade in consumer goods. Beer seems to have loosened up the purse strings and the public feels better."22

On April 8, analysts at Dun \& Bradstreet remarked that "the expansion is more than seasonal and [there are] multiplying evidences of definite confidence" among merchants. ${ }^{23}$ "Better buying interest on the part of the public is observed," noted a Times business article on April 9, which also speculated that "the Easter spurt" could carry forward into continued recovery. ${ }^{24}$ On the same day, the "Financial Markets" column noted "security markets [are] registering the confidence which recent developments in domestic business and finance have inspired. ${ }^{25}$ It is worth noting that all of the sentiments expressed above occurred at least 10 days prior to what Jalil and Rua deem to be the first major event shifting inflation expectations.

Of course, aside from narrative evidence presented above, changes in confidence may be more quantitatively approximated through movements in the stock market (surveys of consumer confidence did not begin until 1952). The DJIA rose 26.9 percent between the end of the Bank Holiday and April 19, the day before the first major shock to inflation expectations outlined by Jalil and Rua (2014). Between April 19 and May 31 the DJIA rose another 29 percent and it is reasonable to assume that much of this jump reflected enhanced inflationary expectations causing economic actors to wish to turn cash, whose value would fall in the face of inflation, into securities.

\footnotetext{
${ }^{22}$ Hughes, C.F. “The Merchant's Point of View," New York Times, April 16, 1933, p. 16N.

23 "Year's Highs Made as Trade Expands," New York Times, April 8, 1933, p. 20.

${ }^{24}$ Hughes, C.F. “The Merchant's Point of View," New York Times, April 9, 1933, p. 15N.

25 "Financial Markets," New York Times, April 9, 1933, p. N7.
} 
Anticipation of NIRA

The National Industrial Recovery Act (NIRA) was passed on June 16, 1933. The Act required industries to form "codes of fair competition" in which firms could draw up rules for pricing, data-sharing, and, in some cases limits on production or new productive capacity. Additionally these codes had to include wage rate increases and reductions in workweeks. Friedman and Schwartz (1963, p. 493) note that the economic spurt the followed the reopening of banks in mid-March was "intensified by production in anticipation" of the NIRA codes which were expected to raise wages and prices. Hugh Johnson, the National Recovery Administration's first administrator similarly suggested in his 1935 memoirs that the rapid recovery in the spring of 1933 was caused by a "rush to speculative production." 26 Both the anticipation of currency depreciation and expectations of higher wages and prices under the NIRA codes caused economic actors "to turn their money into goods to take advantage of this expected [price] rise." ${ }^{27}$ This is broadly consistent with Eggertsson (2012), who claims that the NIRA was expansionary because it increased inflation expectations at a time when the United States faced emergency conditions of excessive deflation and an output collapse.

Additionally, to the extent that firms were considering the possibility of production quotas based on market share under NIRA, it is possible that firms engaged in a race to gain market share in the weeks leading up to the NIRA's passage. One simple way to examine whether anticipation of the NIRA created a "speculative," to use Johnson's words, boost in industrial production is by examining inventories. If firms were producing ahead of demand in anticipation of higher costs or in a race to market share, we would expect to see a large jump in

\footnotetext{
${ }^{26}$ Johnson ,1968 (reprint), p. 190.

${ }^{27}$ Ibid, pp. 190.
} 
inventories. Figure 5 shows that inventories remained constant between March and July 1933, and were well below their level during more normal economics times.

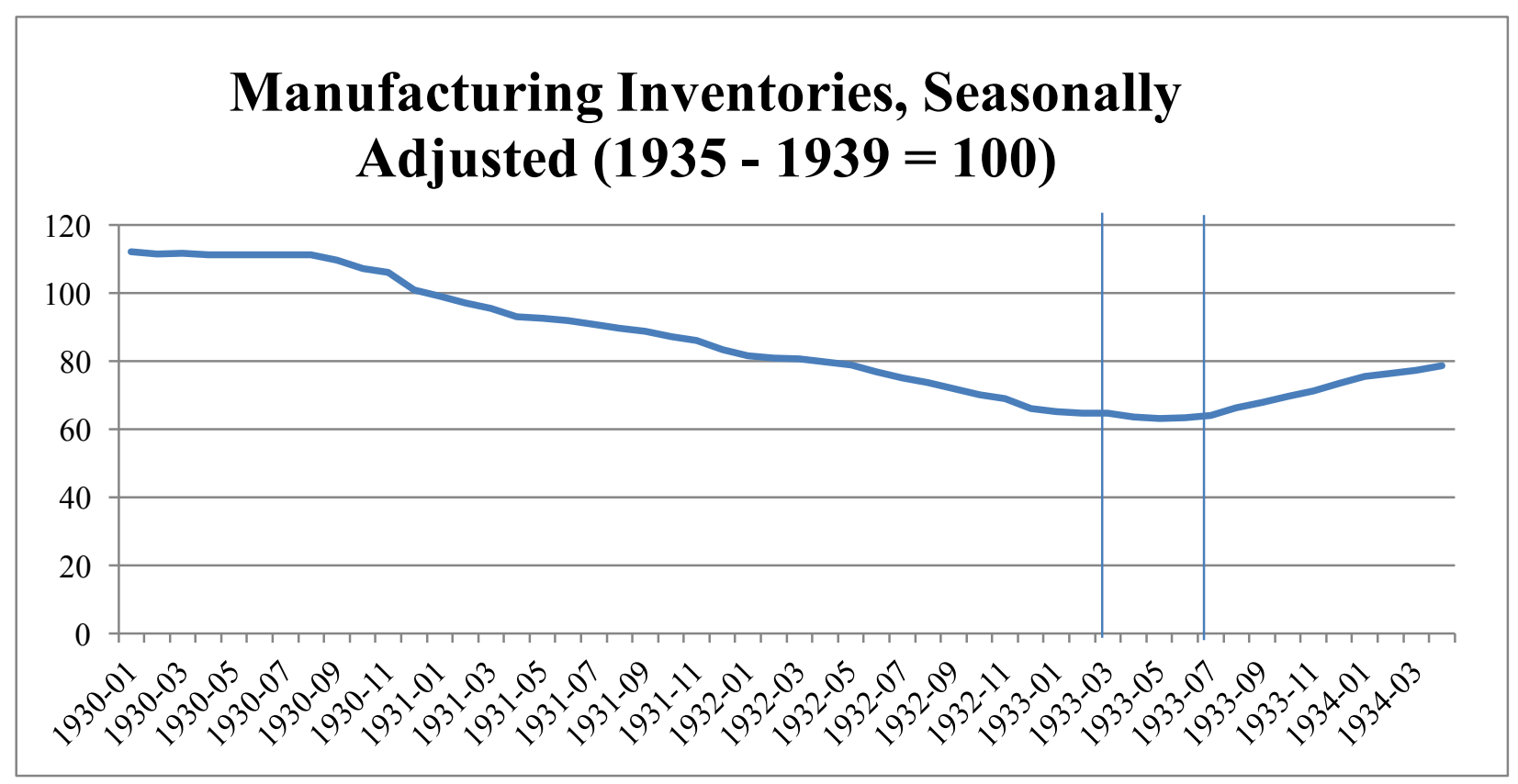

Figure 5

Source: National Industrial Conference Board, "Inventories, Shipments, and Orders, 19291940." Economic Record, Volume 2, Supplement, Dec. 26, 1940. The two vertical lines represent March and July 1933.

This alone does not rule out the hypothesis that anticipation of the NIRA created a "speculative" boom. Consumers and downstream firms, for example, could also have been piling up purchases of final goods in anticipation of higher future prices. But it does show that the increase in industrial production during the spring of 1933 was driven by, or at least coupled with, strong increases in purchases rather than firms engaging in a speculative increase in inventories. 
The other important issue is timing. The first hint of the NIRA was reported in the April 30 New York Times, which cited "news from Washington that a 'national industrial recovery act,' which seems to be one of the most ambitious legislative projects yet undertaken on behalf of the administration, was speedily being prepared." 28 It was speculated that the act could provide price fixing and the abrogation of antitrust laws, as well as emergency control of industry. The same article also noted that end of the week summaries of industrial activity "were more encouraging than at any time since the 'Spring revival' started." A May 5 Journal front page sub-headline read "To Plan or Not to Plan No Longer Seems To Be the Question," 29 and the first industrial action taken in anticipation of the new bill was reported as the garment industry's drafting of an "agreement for stabilization" in the belief that Roosevelt's "program for industrial control would make such action advisable." 30 Still, the lack of contemporary accounts of the NIRA before early May suggest that anticipation of cartelization likely had little to do with the increase in business activity which had, according to the New York Times, been "visibly under way since the middle of March." 31 The recovery seemed self-sustaining well in advance of the hints of NIRA cartelization - anticipation of the NIRA could have further fed into the surge, but it does not appear that it could have been its root cause.

\section{Discussion}

Eggertsson (2008) and Jalil and Rua (2014), following the work of Temin and Wigmore (1990), show that somewhere between half and seven-eighths of the sharp recovery from March

\footnotetext{
28 "Financial Markets: Stocks and Commodities Advance Sharply_Foreign Currencies Rise Against the Dollar," New York Times, April 30, 1933, p. 7N.

${ }^{29}$ Kilgore, Bernard. "Business Control," Wall Street Journal, May 5, 1933, p. 1

30 "Dress Group Works on Trade Compact," New York Times, May 5, 1933, p. 22

31 "Trade Recuperation and Recovery of the Dollar - The President and the Inflation Act," New York Times, May 22, 1933, p. 23
} 
to July 1933 was caused by an increase in inflationary expectations. In this section, we have attempted to evaluate candidates for what could have explained the other 12 to 50 percent of the recovery. Additionally, the narrative analysis suggests that inflation expectations did not accelerate until after April 19, but it appears that the economy had already begun a solid recovery before that date so we are particularly interested in factors that could have driven recovery during the second half of March and the first half of April.

We do not find any statistically significant direct effects on recovery from the rehabilitated banking system. In fact, while total bank loans did rise a bit from their March 1933 trough, they remained below their 1930-1932 levels throughout 1933 . We believe increases in consumer and business confidence-inspired by Roosevelt-likely played some role, independent of inflationary expectations. We do find strong evidence consistent with devaluation, which began at the end of April, playing a direct role in the recovery (it also likely played an indirect role through inflation expectations). Our empirical analysis suggests that industries that were more positively sensitive to trade-particularly exports — saw faster growth during Recovery Spring than otherwise. Finally, data on inventories do not appear consistent with the notion of anticipation of the NIRA causing firms to produce in advance of demandeither to race to gain market share before cartel codes were put in place or to try to produce ahead of demand before production costs rose.

\section{Faltering Fall: August to November 1933}

Between its peak in July 1933 and trough in November 1933, Industrial Production fell 19 percent, the Index of Business Activity fell 20 percent, and Manufacturing Production fell 31 percent, making this four-month downturn one of the sharpest in US history. As a first step in 
our analysis, we repeat the first stage of the industry-level event study model employed above but redefine the event window to the Faltering Fall period. When we do this we find the cumulative abnormal return to be -0.27 with a robust standard error of 0.12 . This suggests that the sudden drop in output between July and November 1933 cannot be explained by the variables in the model. Additionally in the second stage regressions the cumulative abnormal return was not statistically related to the coefficients on banking sector health or exports, suggesting something else caused the downturn.

What could cause the unprecedented recovery of March to July to turn sharply into severe downturn? Weinstein (1980) contends that the NIRA, passed on June 16, obstructed the recovery. Temin and Wigmore (1990) argue that this is unlikely since the NIRA would have further fed into inflationary expectations. Temin and Wigmore (1990, p. 499) claim instead that the slowdown was caused by "an apparent weakening of Roosevelt's commitment to devaluation... Fortunately, the dollar resumed its fall and the recovery was not aborted." Indeed, Jalil and Rua (2014) provide narrative evidence consistent with the notion that inflation became far less certain in August. For example Moody's described Roosevelt's inflation policies as "confusing" in September and by October noted that a "clearer shift in the direction of more conservatism" with regard to inflation had occurred (Jalil and Rua, 2014, p. 54). However, Jalil and Rua (2014, p. 51) note that Moody's also cited the NIRA as "one of the original causes of the recession in business since July," a contention that was echoed by the Magazine of Wall Street. Jalil and Rua conclude that further research is necessary to distinguish between the two competing explanations for the downturn.

An examination of the dollar versus several important currencies, such as the French franc, the German reichsmark, and the British pound, shows that the dollar fell sharply against 
these currencies (38.6 percent, 39.5 percent, and 35.5 percent respectively) between March and July 1933. ${ }^{32}$ Then in August, the dollar rose between 1.5 and 3 percent against all three, consistent with Temin and Wigmore. However, after a one month blip, the dollar continued to depreciate, falling by between 16.5 percent and 17 percent against these three currencies between August and November 1933. These movements in the dollar, while perhaps offering some explanation for the start of the August downturn, cannot explain the depth, or full timing, of the recession that occurred between July and November 1933.

We put forth a somewhat modified hypothesis - that the downturn was at least partially brought about by sharp hourly wage rate increases mandated by the President's Reemployment Agreement (PRA), which was a subprogram within the NIRA. The PRA, which went into effect on August 1, 1933 - aligning with the economic turning point in the data-had two major prongs. First firms that signed onto the PRA agreed to pay a minimum wage that was generally 40 cents per hour. President Roosevelt also encouraged firms to raise hourly wage rates of those workers already making above this minimum. Second, to promote work-sharing, firms agreed to a maximum workweek of 35 hours (40 hours for sales or clerical workers). According to Taylor (2011), the logic behind the PRA was to promote reemployment by spreading scarce work amongst more Americans - approximately three workers could be employed at 35 hours per week where previously only two would have worked for 48 or 50 hours. The increases in hourly wage rates ensured that workers' take-home pay would not fall dramatically even though they were working fewer hours.

\footnotetext{
${ }^{32}$ Exchange rate data are from "Banking and Monetary Statistics, 1914-1941." Board of Governors of the Federal Reserve System, 1943. https://fraser.stlouisfed.org/title/?id=38
} 
According to the Roosevelt Administration, these labor restrictions covered 85 percent of all employers in the US by September 1933 (Taylor, 2011, p. 138). Although signing the PRA was voluntary, the program had high uptake because signing firms were able to display the Blue Eagle emblem, which could be obtained at local post offices once the agreement was signed, on their products, advertisements, or in their store windows - and Roosevelt strongly encouraged Americans to reward merchants bearing the Blue Eagle by shopping only at these establishments. Firms who violated their signed PRA agreement could have the right to display the Blue Eagle taken away. Taylor (2007) and Taylor and Klein (2008) demonstrate that the Blue Eagle affected economic behavior

Table 4 shows monthly movements in hourly earnings, average work weeks, number of workers on payrolls, and total labor hours worked—all in the manufacturing sector—for 1933. The effects of the PRA seem clear as hourly wage rates rise around 20 percent and workweeks fall around 21 percent in the two months after the program begins in August. Furthermore, despite the steep drop in production, the number of workers employed actually rises thanks to the work-sharing induced shorter workweeks. Taylor's (2011) empirical analysis suggests that changes in wages and hours were caused by the PRA rather than other factors.

To examine the extent that the PRA wage increases could have contributed to the sharp reversal in recovery that began coincident to its August implementation, we employ crosssectional regressions for 25 industries. The dependent variable is the growth rate in an industry's output between July 1933 and November 1933 (peak to trough of the downturn that occurred in the late summer and fall of 1933) minus the growth rate of the same industry's output between July and November 1932. By looking at the change in the growth rates between these months across two different years, we help control for any seasonal variation that might otherwise bias 
the results. ${ }^{33}$ The key independent variable of interest is the industry's hourly earnings in July 1933. Taylor (2011) shows that the wage rates of those industries already paying high wages were less affected by the PRA since the wage guideposts were less binding for them. We therefore hypothesize that high-wage industries would have experienced smaller output drops than otherwise if the downturn was caused by exogenous wage increases from the PRA.

Table 4: Monthly Movements in Labor Data, 1933 Months Following the President's Reemployment Agreement in Italics

\begin{tabular}{|c|c|c|c|c|}
\hline & $\begin{array}{c}\text { Average Hourly } \\
\text { Earnings (Cents), } \\
\text { Manufacturing }\end{array}$ & $\begin{array}{c}\text { Average Work } \\
\text { Week (Hours), } \\
\text { Manufacturing }\end{array}$ & $\begin{array}{c}\text { Employment, \# of } \\
\text { Workers on Payrolls, } \\
\text { (Thousands) } \\
\text { Manufacturing }\end{array}$ & $\begin{array}{c}\text { Total Labor Hours } \\
\text { Worked } \\
\text { (Millions) } \\
\text { Manufacturing }\end{array}$ \\
\hline January 1933 & 46.6 & 35.1 & 5110 & 179.4 \\
\hline February 1933 & 46.2 & 35.6 & 5227 & 186.1 \\
\hline March 1933 & 45.9 & 32.1 & 5029 & 161.4 \\
\hline April 1933 & 46.0 & 34 & 5160 & 175.4 \\
\hline May 1933 & 45.3 & 37.6 & 5399 & 203.0 \\
\hline June 1933 & 45.0 & 41.5 & 5781 & 239.9 \\
\hline July 1933 & 45.6 & 42.9 & 6155 & 264.0 \\
\hline August 1933 & 50.7 & 38.2 & 6570 & 251.0 \\
\hline September 1933 & 53.6 & 36.3 & 6860 & 249.0 \\
\hline October 1933 & 54.2 & 36.1 & 6827 & 246.5 \\
\hline November 1933 & 54.6 & 33.8 & 6555 & 221.6 \\
\hline December 1933 & 55.0 & 33.8 & 6413 & 216.8 \\
\hline
\end{tabular}

Consistent with this hypothesis, specification (1) of Table 5 shows that an industry whose July 1933 wage rate was one cent higher, grew 2.87 percent faster (or more correctly, fell 2.87 percent less) during the downturn of July to November of 1933 than otherwise. In other words,

${ }^{33}$ To illustrate the Paper Production industry saw output grow by 16.33 percent between July and November 1932, but fall by 14.98 percent between July and November 1933. Thus the dependent variable takes on a value of $-14.98-16.33=-31.31$ for Paper Production. As a robustness check, we took an alternative approach and employed the growth in industry output between July and August 1933 as the dependent variable and included the growth in the same measure between July and August 1932 as an independent variable. The results reported in Table 5 are essentially unchanged. 
low-wage industries like clothing and shoe production experienced a larger downturn in the fall of 1933 than did high-wage industries like automobile and machine tool manufacturing. This evidence is consistent with a story whereby wage increases helped trigger the slowdown since the wage increases would have had their largest impact upon the industries that performed worst during this period.

\section{Table 5 \\ Causes of Faltering Fall, July to November 1933 \\ Dependent Variable:}

(Growth Rate Output July to November 1933) - (Growth Rate Output July to November 1932) (P-values in parentheses)

(1)

Constant

Wage July 1933

Capacity Utilization,

(Output July 33/July 29)

Percent Output Growth

Spring 1933

Wage Growth

July to November 1933

Adjusted R-squared

F-statistic

Observations

$$
\begin{array}{ll}
-172.28 & -70.63
\end{array}
$$

$\begin{array}{cc}2.87 & 1.75 \\ (0.06) & (0.01)\end{array}$

$$
-20.01
$$

$-0.227$

(0.00)

$-0.209$

$-1.26$

$(0.01)$

$\begin{array}{ccc}.181 & .561 & .540 \\ 5.07 & 10.81 & 7.74 \\ 25 & 24 & 24\end{array}$

Notes: All regressions employ White heteroskedasticity-consistent standard errors and covariance. Specifications 2 and 3 have one less observation since output data for the rayon industry is not available for July 1929. The variable "Output Growth Spring 1933" is the growth rate in output between March and July 1933 minus the growth rate in output between March and July 1932 , following the same logic as the dependent variable. 
Specification (2) introduces two control variables; how close the industry was to its productive capacity in July 1933 (measured by dividing output in July 1933 by output near the peak of the prior business cycle in July 1929-again the same months are used to control for seasonality) and how quickly did the industry's output grow between March and July 1933. Interestingly, there is strong evidence that the industries that experienced the most rapid growth during the spring of 1933 were also the ones who saw the largest decline in the fall of 1933 - this is true even holding wage and capacity utilization constant. Additionally, those industries that were operating closer to capacity generally saw larger declines in output during the downturn of fall 1933, other factors constant. Most importantly, the coefficient on the wage in July 1933 remains positive and significant when these control variables are introduced, consistent with the notion that those industries which were most affected by the PRA saw the largest downturns.

Specification (3) employs a different wage variable - the growth in the wage rate between July and November 1933. The use of this variable would seem to create an endogeneity issue since one would generally expect output and wage growth to move endogenously. The inclusion of wage rates as an independent variable would be valid, however, if wage rate changes under the PRA were exogenous, which is our contention. In fact, the negative and statistically significant coefficient on wage rate growth offers strong — and more direct — evidence that those industries where the PRA caused wages to rise the most in the four months after the agreement went into effect also saw the largest drops in output during that time. The endogeneity issue, to the extent that it exists, should bias the coefficient upward, making the evidence of a negative relationship all the more compelling. A one percent increase in nominal wage rate growth was associated with a 1.26 percent decline in output growth during the fall of 1933 . 
The results in Table 5 are consistent with the view that the wage-raising PRA played a role in the nascent recovery's abrupt reversal in August. That the PRA played an important role in cutting off the recovery of 1933 aligns with Cohen-Setton, Hausman, and Wieland (2014), who show that when France adopted strict wage and hour policies in 1936, which they likened to the "NIRA on steroids," an inflation-expectations induced recovery was aborted.

On the other hand, the negative and statistically significant coefficient on growth during Recovery Spring is consistent with the notion that the same factor that drove the recovery between March and July reversed itself and brought the slowdown between August and November. More specifically, it aligns with Temin and Wigmore's (1990) story that inflation expectations were on the rise during the spring and early summer-causing output to rise in the industries most sensitive to such expectations - and then fell in the later summer and fall and caused output to decline in these same industries. The economy's reversal in fortune could have been caused by both a waning of inflation expectations and the sharp hourly wage increases that went into effect on August 1, 1933 under the President's Reemployment Agreement.

Another event that began in the late summer and early fall of 1933 was the adoption of industry-wide "codes of fair competition" under the NIRA. Thirty industries had codes approved by September 18, and by the end of October 75 industries were covered. Within the codes, firms could agree to rules requiring the sharing of data, restrictions on output, factory hours, and new capacity, restrictions on pricing behavior, as well as a host of other measures. Eggertsson (2012) argues that even though the NIRA cartels created a negative supply-shock, the legislation would have been expansionary because it would have raised inflation expectations and thus helped the nation escape from the emergency economic conditions that created a deflationary spiral. 
Contrary to this, Cole and Ohanian (2004) employ a dynamic stochastic general equilibrium model to show that the NIRA cartelization policies slowed recovery.

It certainly could be true that, other factors constant, the increases in inflation expectations that the NIRA created, beginning with the first hints of its creation at the end of April, could have boosted the economy, consistent with Eggertsson. But if the deflationary spiral had been broken and the economy was on a growth path away from the emergency conditions, the negative supply-shock of high wages and cartelization that hit in the late summer and fall of 1933 could have had the negative effect demonstrated by Cole and Ohanian. To employ an analogy, expectations of a major storm can spur economic activity as households stock up, but once the storm itself hits, economic activity falls as economic actors are restrained. The NIRA, like the storm, can be both expansionary in the dimension highlighted by Eggertsson and contractionary in the one highlighted by Cole and Ohanian. Still, the storm analogy is a bit of an oversimplification since for Eggertsson (2012) the key is that a negative supply shock such as the NIRA wage and cartelizization policies would increase GDP because in his model (with emergency economic conditions) the Aggregate Demand curve slopes upward. The empirical issue then is whether the negative supply shock caused both prices and output to rise under the NIRA — as would be true if the AD curve sloped upward — or whether the negative supply shock caused prices to rise and output to fall, as would be the case with a downward sloping demand curve.

In addition to showing output, employment, and average hourly work weeks for March and July 1933 for six major industries, Table 3 also shows these data points for November 1933. Output and total labor input fell in five out of the six industries between July and November 1933 - dropping by over 50 percent in the Automobile and Steel industries. It is interesting to 
note that for the two industries in Table 3 that were not hit hard during the downturn in the fall of 1933 - Chemical Manufacturing and Machinery - the NIRA codes of fair competition were not passed until February and March of 1934, respectively. The Steel and Automobile codes were passed in August, Shoe Manufacturing in October, and Paper and Pulp in November. This is consistent with Taylor's $(2007 \mathrm{~b}, 2010,2011)$ panel analyses of over 60 industries showing that during the months an industry was covered by a code of fair competition, its output was lower than otherwise, consistent with cartel theory.

Why Did the Recovery Start Again in December 1933?

Between November 1933 and June 1934, Industrial Production and the Index of Business Activity rose around 11 percent. If the NIRA wage and cartel policies were harmful and were still in place, why did the economy not continue to regress? The economy experienced several favorable tailwinds beginning in December 1933. The money supply began to grow steadily, rising 8.2 percent between December 1933 and July 1934. Government spending also jumped significantly_much of it driven by the Civil Works Administration emergency public works projects - in the winter and spring of 1934. Furthermore, while hourly wage rates continued to rise in early 1934, they did so at a much slower rate-they rose 20 percent between July and November 1933, but then rose only 7 percent between November 1933 and June 1934. With respect to currency movements, the dollar ceased its downward trend and rose around 2 percent in December 1933, before falling again -7.7 percent against the franc and 3 percent against the pound-between December 1933 and June 1934. A final tailwind, if one takes the view that cartelization was economically harmful during this time, is that the NIRA cartels underwent a 
"compliance crisis" in early 1934 whereby firms abandoned the cartel agreements. Taylor and Klein (2008), following up on Irons (1982), Brand (1988), and Alexander (1994), amongst others, highlighting the NIRA compliance crisis, show that enthusiasm for the law and the Blue Eagle peaked in October 1933 and that as it waned, firms began to defect from the cartel agreements. When the government did not follow through on threats to fine and imprison violators, much less take away their right to display the Blue Eagle emblem, more defections occurred. In February 1934, the wife of Pennsylvania governor Gifford Pinchot noted that "Blue Eagles are adorning sweat shops in hundreds of towns in Pennsylvania" because of the lack of government enforcement against NIRA violators (quoted in Taylor and Klein, 2008, p. 260).

\section{The Roosevelt Recession}

The recession of 1937-1938 was quite different from the events of 1933 studied above. Most notably was the absence of a banking crisis (or, perhaps more importantly, its resolution) or major changes in currency regimes. As past scholars (Brown, 1956; Friedman and Schwartz, 1963; Romer, 1992; Meltzer, 2003; Irwin, 2012) who study the so-called "Roosevelt Recession" note, there were important changes in the money supply and government spending. Most related to our work, however, Eggertsson and Pugsley (2006) argue that confusing signals emanating from the Roosevelt Administration and the Federal Reserve in early 1937 regarding future price movements were responsible for the downturn. They argue that a series of anti-inflationary communications made agents no longer believe that policy makers were committed to restoring the price level to pre-Depression levels. Between February and April 1938, the Roosevelt Administration recommitted to inflation, and the downturn ended in June of that year. 
Thus, it might be interesting to duplicate our event-study analysis of 1933 for the Roosevelt Recession. For the 1937-38 analysis, we define the estimation window as July 1921 through December 1936. We then define two different event windows (estimated separately)May of 1937 to June 1938 and June 1938 to December 1938, respectively the recession and start of the recovery. As before, we compute the cumulative abnormal returns for each event window.

The average cumulative abnormal return in the recession event was -0.26 with a robust standard error of 0.11. Recall that the first-stage included fiscal and monetary factors - if such factors were solely responsible for the downturn, the abnormal return would have been statistically zero. With respect to the second stage, the estimated coefficients on excess reserves and exports were statistically insignificant, suggesting that neither trade nor the health of the banking system played a major role in the downturn. This is not surprising given the lack of major structural policy changes in currency or the financial system. These results are consistent with Eggertsson and Pugsley's (2006) contention that inflation policy uncertainty—specifically changes in expectations from an inflationary policy to a deflationary one-contributed to the downturn. Alternatively, the results could also be viewed as consistent with Vedder and Gallaway's (1993) contention that a spike in wages following the April 1937 Supreme Court ruling upholding the National Labor Relations Act, contributed to the downturn.

With respect to the recovery event window (the last half of 1938), the average cumulative abnormal return in the recession event was 0.06 with a robust standard error of 0.08 . As before, the estimated coefficients on excess reserves and exports in the second stage were statistically insignificant. These results suggest that the recovery of late 1938 was largely explained by the variables in our first stage, such as factors related to fiscal or monetary policy. This is consistent 
with current literature suggesting that a reversal from contractionary to expansionary fiscal and monetary policy helped promote recovery from the Roosevelt Recession.

\section{Conclusion}

There can be no doubt that the surge in recovery that occurred immediately after Roosevelt took office was extraordinary. No five-month period in US history has seen a jump in industrial production even half as large as that which was experienced between March and July 1933. Temin and Wigmore (1990) and Eggertsson (2008) credit the recovery to a major positive "regime change" which brought a significant change in inflation expectations. Roosevelt devalued the dollar and brought an end to the "one big deflation" that had preceded it. Still, the recovery ended abruptly in August 1933 and the drop in output over the following four months was one of the sharpest in US history.

This paper focuses on two questions - what factors lead to the sharp recovery between March and July 1933 and what factors caused the economy to revert back into a sharp decline beginning in August 1933? With respect to the first question, Temin and Wigmore (1990), Eggertsson (2008) and Jalil and Rua (2014) have suggested that the lion's share-between half and seven-eighths — of the recovery can be explained by a jump in inflation expectations. We agree that inflation expectations played a major role in the growth between March and July. Still, Jalil and Rua (2014) suggest that the first major shocks to inflationary expectations did not occur until late April and we show that the recovery was well under way by this date-although it clearly did accelerate along with rising expectations of higher prices. Furthermore, we are interested in explaining what factors could have been responsible for the other one-eighth to one- 
half of the rapid growth in output between March and July. Our examination of the historical narrative suggest that a relative return to health of the financial system after the Emergency Banking Act, increased confidence, and currency devaluation (independent of devaluation's effect on inflation expectations) each played important supporting roles in the recovery and that some combination of the first two are likely responsible for the turning of the corner in late March and early April.

With respect to Faltering Fall - the severe downturn between August and November of 1933 - our analysis suggests that the introduction of the President's Reemployment Agreement on August 1, 1933, which sharply raised hourly wage rates, contributed to the setback.

\section{REFERENCES CITED}

Alexander, Barbara (1994). "The Impact of the National Industrial Recovery Act on Cartel Formation and Maintenance Costs.” Review of Economics and Statistics, 76, 245-54.

Bernanke, Benjamin S. (1983) "Nonmonetary Effects of the Financial Crisis in the Propagation of the Great Depression.” American Economic Review 73, 257-276.

Brand, Donald (1988). Corporatism and the Rule of Law: A Study of the National Recovery Administration. Ithaca: Cornell University Press.

Brown, E. Carey (1956). "Fiscal Policy in the Thirties: A Reappraisal." American Economic Review 46: 857-879. 
Carroll, Christopher D., Jeffrey C. Fuhrer and David W. Wilcox (1994). "Does Consumer Sentiment Forecast Household Spending? If So, Why?" American Economic Review 84, 77-84.

Cecchetti, Stephen G. (1992) "Prices During the Great Depression: Was the Deflation of 19301932 Really Unanticipated?" American Economic Review 82, 141-156.

Cohen-Setton, Jérémie, Joshua K. Hausman, and Johannes F. Wieland "Supply-side policies in the Depression: Evidence from France." Working paper retrieved from http://wwwpersonal.umich.edu/ hausmanj/Cohen Setton Hausman Wieland.pdf

Dighe, Ranjit (2011). "Saving Private Capitalism: The U.S. Bank Holiday of 1933.” Essays in Economic and Business History 29, 41-58.

Eggertsson, Gauti B. (2008). "Great Expectations and the End of Depression." American Economic Review 98, 1476-1516.

Eggertsson, Gauti B. (2012). “Was the New Deal Contractionary?” American Economic Review 102, No. 1: 524-555.

Eggertsson, Guati B. and Benjamin Pugsley (2006). "The Mistake of 1937: A General Equilibrium Analysis.” Monetary and Economic Studies (Bank of Japan) 24: 151-190.

Friedman, Milton and Schwarz, Anna J. (1963). A Monetary History of the United States, 18671960. Princeton: Princeton University Press.

Hausman, Johsua K. (2013). New Deal Policies and Recovery from the Great Depression. Doctoral dissertation retrieved from http://www.escholarship.org/uc/item/1sr8n2x6 
Hamilton, James D. (1992). "Was the Deflation During the Great Depression Anticipated? Evidence from the Commodity Futures Market." American Economic Review 82, 157178.

Himmelberg, R. F. (1993). The Origins of the National Recovery Administration: Business, Government, and the Trade Association Issue, 1921-1933. New York: Fordham University Press.

Jalil, Andrew and Gisela Rua (2014). "Inflation Expectations and Recovery from the Depression in 1933: Evidence from the Narrative Record." Working Paper available at http://papers.ssrn.com/sol3/papers.cfm?abstract id=2325219

Johnson, H. S. (1935). The Blue Eagle, from Egg to Earth. Garden City, NY: Doubleday, Doran, \& Co.

Irons, Peter. H. (1982). The New Deal Lawyers. Princeton: Princeton University Press.

Irvin, Douglas A. (2012). "Gold sterilization and the recession of 1937-1938." Financial History Review 19: 245 - 267.

Levine, Ross. (1997) "Financial Development and Economic Growth: Views and Agenda." Journal of Economic Literature 35, 688 - 726.

Matsusaka, John G. and Argia M. Sbordone (1995). "Consumer Confidence and Economic Fluctuations.” Economic Inquiry 33, 298 - 318.

Meltzer, Allan H. (2003). A History of the Federal Reserve, Volume 1: 1913-1951. Chicago: University of Chicago Press, 2003.

Rajan, Raghuram G.and Luigi Zingales (1998). "Financial Dependence and Growth.” American Economic Review 88, 559 -586. 
Romer, Christina D. (1990). "The Great Crash and the Onset of the Great Depression." Quarterly Journal of Economics, 105, 597-624.

Romer, Christina D. (1992). "What Ended the Great Depression?” Journal of Economics History 52: 757-784.

Sargent, Thomas J. (1983) “The Ends of Four Big Inflations.” In Inflation: Causes and Effects, Ed. Robert Hall, 41-97, Chicago: University of Chicago Press.

Schumpeter, Joseph A. (1911) A Theory of Economic Development. Cambridge, MA: Harvard University Press.

Sumner, Scott (2012). "Explaining High Frequency Output Fluctuations during the Great Depression.” Presented at American Economic Association meetings, January 2012.

Taylor, Jason E. (2007a). "Buy Now! Buy Here!: The Rise and Fall of the Patriotic Blue Eagle Emblem, 1933-1935." Essays in Economic and Business History 25, 117-130.

Taylor, Jason E. (2007b). "Cartel Code Attributes and Cartel Performance: An Industry-level Analysis of the National Industrial Recovery Act." The Journal of Law and Economics $50,597-624$.

Taylor, Jason E. (2010). "The Welfare Impact Of Collusion Under Various Industry Characteristics: A Panel Examination Of Efficient Cartel Theory" The B.E. Journal of Economic Analysis \& Policy: Vol. 10: Iss. 1 (Contributions), Article 97.

Taylor, Jason E. (2011). “Work-Sharing During the Great Depression: Did the 'President's Reemployment Agreement' Promote Reemployment?” Economica 78, 133-158. 
Taylor, Jason E. and Peter G. Klein (2008). “Anatomy of a cartel: The National Industrial Recovery Act of 1933 and the compliance crisis of 1934." Research in Economic History 26, 235-271.

Taylor, Jason E. and Todd C. Neumann (2013). "The Effect of Institutional Regime Change Within the New Deal on Industrial Output and Labor Markets." Explorations in Economic History 50, 582-598.

Temin, Peter, and Barrie A. Wigmore (1990). “The End of One Big Deflation.” Explorations in Economic History 27, 483-502.

Vedder, R. K. and Gallaway, L. E. (1993). Out of Work: Unemployment and Government in Twentieth-Century America. New York: Holmes and Meier.

Weinstein, Michael M. (1980). Recovery and Redistribution under the NIRA. Amsterdam: NorthHolland. 